\title{
Physical and Biophysical Pretreatment of Water Hyacinth Biomass for Cellulase Enzyme Production
}

\author{
F. Amriani, ${ }^{\text {a,b, }}{ }^{*}$ F. A. Salim, ${ }^{\text {b I. Iskandinata, }},{ }^{\text {b D. Khumsupan, }{ }^{\mathrm{c}} \text { and Z. Barta }}$ \\ Indonesian Institute of Sciences, Research Center for Chemistry, \\ Kawasan Puspiptek Serpong 15314, Indonesia \\ bepartment of Chemical Engineering University \\ of North Sumatera Padang Bulan, Medan 20155, Indonesia \\ 'The Petroleum and Petrochemical College, Center of Excellence \\ for Petrochemical and Materials Technology, \\ Chulalongkorn University, Bangkok 10330, Thailand \\ dDepartment of Applied Biotechnology and Food Science, \\ Faculty of Chemical Technology and Biotechnology, Budapest \\ University of Technology and Economics, Budapest 1111, Hungary
}

doi: 10.15255/CABEQ.2015.2284

Original scientific paper

Received: July 27, 2015

Accepted: June 9, 2016

One practical way to control water hyacinth overgrowth due to eutrophication is by utilizing it as a substrate to produce cellulase. Water hyacinth was subjected to pretreatment to degrade lignin and improve microbes' accessibility to cellulose. Physical and biophysical pretreatment methods were investigated. Biomass size reduction was performed in the physical pretreatment whereas white rot fungus (Ganoderma boninense) was used in the biophysical pretreatment. Cellulase-producing fungi, Aspergillus niger and Trichoderma reesei, were exploited in this study. Although lignin content was reduced by two-fold after the biophysical pretreatment, the maximum production of cellulase occurred when only the physical pretreatment was employed on the substrate. It may be because the higher apparent crystallinity of cellulose in physical pretreatment triggers more cellulase production compared to that in biophysical pretreatment. The maximum cellulase activity was found to be $1.035 \mathrm{IU} \mathrm{mL}^{-1}$ when water hyacinth was only physically pretreated.

Key words:

Aspergillus niger, cellulase, cellulose, pretreatment, Trichoderma reesei, water hyacinth

\section{Introduction}

Water hyacinth (Eichhornia crassipes) is known as a weed aquatic plant because it severely disrupts aquatic ecosystems and emerges due to eutrophication. The overgrowth of water hyacinth results in various ecological and socio-economic issues. ${ }^{1}$ It has become a particular concern in Africa, Asia, and North America. ${ }^{2}$ The International Union for Conservation of Nature (IUCN) has classified water hyacinth as one of a hundred invasive plant species. ${ }^{3}$ Presently, the plant is eliminated by burning, which serves as a short-term solution; the burning may even initiate another environmental problem. Water hyacinth is a lignocellulosic material, which can be converted into useful products.

Recently, conversion of agro-waste into practical fuel like bioethanol has received substantial interest because agro-waste is available in abundance. The techniques used in the conversion vary depend-

"Correspondence: feni.amriani@lipi.go.id or feni_chem1@yahoo.com ing upon the type of biomass and the production costs. One of the most essential and expensive steps is the pretreatment process. The purpose of pretreatment is to disrupt the physical and chemical structure of biomass in order to make cellulose become more susceptible to further hydrolysis. ${ }^{4}$ Research of pretreatment methods for lignocellulosic materials is often performed either in laboratory or pilot scale.

Chemical and physical pretreatment methods for lignocellulosic biomass are widely used in several studies. Chemical pretreatment often involves large amounts of chemicals at high concentration in order to degrade lignin and allow cellulase-producing microbes to easily hydrolyze cellulose ${ }^{5,6} \mathrm{Al}-$ though chemical and physical methods do not require a long time, they consume large amounts of energy and generate chemical waste. ${ }^{7}$ Hence, this study is focused on a more environmentally friendly approach through a biological method to minimize the waste.

The use of microorganisms in both biological pretreatment and cellulase production is crucial. 
White rot fungus (Ganoderma boninense), a pathogenic fungi that affects oil palm tree, is often used in biological pretreatments. ${ }^{8}$ The Ganoderma family also possesses the ability to degrade lignin. ${ }^{9}$

Enzymatic hydrolysis is considered the most efficient and least polluting method to generate glucose from lignocellulosics. However, the expense of hydrolyzing enzyme, such as cellulase, is still costly. In addition, the production economics of bioethanol is largely dependent on the price of cellulase. ${ }^{10}$ Thus, further research should investigate the production of cellulase in order to reduce the cost.

Cellulase is the third largest industrial enzyme in the world. It has gained increasing interest, particularly in the bioconversion of lignocellulosic biomass. ${ }^{11}$ Cellulase is heavily used in several industries including food, textile, paper, bioethanol, ink, and pulp processing. ${ }^{12,13}$ Only certain microorganisms can utilize cellulose as an energy source to produce a complete cellulase complex. The complete cellulase complex consists of three main components: endo- $\beta$-glucanase, exo- $\beta$-glucanase, and $\beta$-glucosidase. Commercial cellulase-producing microbes are generally limited to Trichoderma reesei, Aspergillus niger, Thermomonospora fusca, and Bacillus sp. ${ }^{14}$ Thus, the production of cellulolytic enzymes by $A$. niger and $T$. reesei from physically and biophysically pretreated water hyacinth are investigated in this study. The pretreatment effect is also examined by determining the alteration of structure composition and cellulose crystallinity after pretreatment. Moisture content and incubation period are the parameters that are observed and reported.

\section{Materials and methods}

\section{Materials}

All chemicals used in this study were obtained from Merck, Tbk, Jakarta-Indonesia in analytical grade. Potato dextrose agar (PDA) from Oxoid ${ }^{\mathrm{TM}}$, 3,5-dinitrosalicylic acid and CM-cellulose were purchased from Sigma-Aldrich (Singapore).

\section{Preparation of microorganisms}

White rot fungus ( $G$. boninense) was isolated from uprooted oil palm given by the Department of Biology, University of North Sumatera. A. niger and $T$. reesei were obtained from Bandung Institute of Technology. The strains were cultivated on potato dextrose agar (PDA) slants/plates at $30{ }^{\circ} \mathrm{C}$ for 72 hours. ${ }^{15}$ A sterilized wire loop was used to collect $A$. niger or $T$. reesei. The loop was dipped in a liquid medium containing sucrose $22 \%(\mathrm{w} / \mathrm{v}),\left(\mathrm{NH}_{4}\right)_{2} \mathrm{SO}_{4}$ $1 \%(\mathrm{w} / \mathrm{v}), \mathrm{KH}_{2} \mathrm{PO}_{4} 1 \%(\mathrm{w} / \mathrm{v})$, and incubated at $30{ }^{\circ} \mathrm{C} .{ }^{16}$

\section{Preparation and pretreatment of water hyacinth}

Water hyacinth was collected from the local water bodies at Lhokseumawe-Medan, Indonesia. The collected plant was subjected to physical and biophysical pretreatment as shown in the scheme (Fig. 1). The physical pretreatment was conducted through the combination of chopping, drying at $105^{\circ} \mathrm{C}$, and grinding to the size of $0.1-1 \mathrm{~mm}$. The ground water hyacinth was stored in a dry container

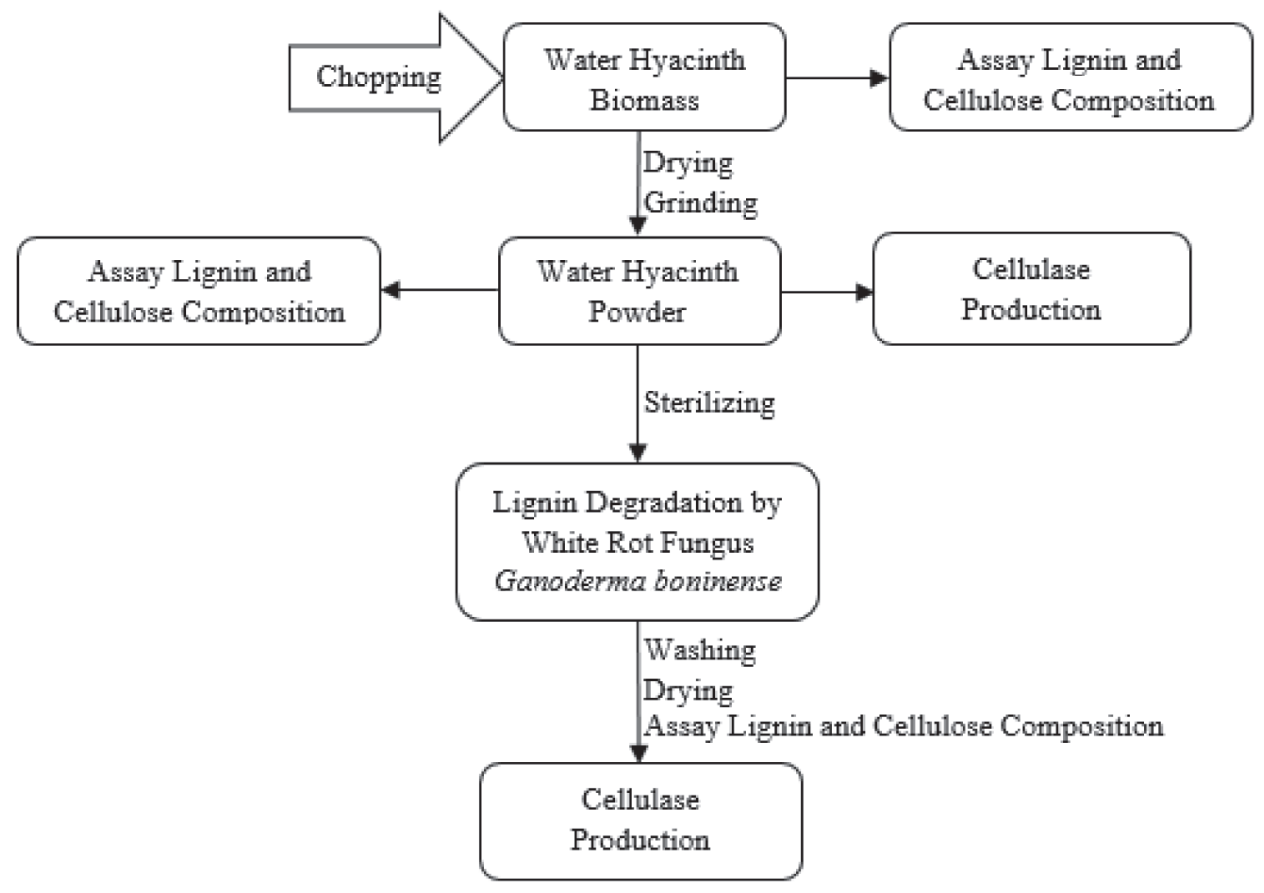

Fig. 1 - Pretreatment scheme 
at room temperature. The composition of lignin and cellulose was examined prior to and after the physical pretreatment.

The biophysical pretreatment was conducted by using white rot fungus, $G$. boninense, to degrade lignin in water hyacinth. The 7-day biological degradation process was carried out with additional nutrient according to Mandel Weber medium ${ }^{17}$ at $\mathrm{pH} 5$ and $70 \%(\mathrm{w} / \mathrm{v})$ moisture content. The sample was washed and dried after the process. The dried sample was assayed to determine lignin and cellulose content.

\section{Compositional analysis}

The composition of lignin and cellulose in water hyacinth was evaluated using Chesson method. ${ }^{18}$ Wide angle X-Ray Diffraction (XRD) was used to measure crystallinity of the substrate. The percentage of apparent crystallinity in water hyacinth after physical and biophysical pretreatments was measured by XRD Peak Height Method. ${ }^{19,20}$ The XRD measurements were performed using Philips Analytical System with PC-APD and Diffraction software (Bandung Institute of Technology).

\section{Enzyme production}

The pretreated water hyacinth was fermented using solid-state fermentation (SSF) method. The enzyme production experiments were carried out in 250-mL Erlenmeyer flasks containing $10 \mathrm{~g}$ of substrate. The effect of moisture content $65,70,75,80$, and 85 (\% of wet mass) was studied to find the maximum cellulase production with Mandel Weber medium. The initial $\mathrm{pH}$ for medium was adjusted to $5 .^{21}$ Then, the medium was autoclaved at $120{ }^{\circ} \mathrm{C}$ for 15 minutes, cooled, and inoculated with $15 \%(\mathrm{w} / \mathrm{w})$ suspension. ${ }^{22}$ The inoculated flasks were incubated in a temperature-controlled shaker at $30{ }^{\circ} \mathrm{C}^{23,24}$ for $3,5,7,8$, and 9 days. The effect of mono and mixed microbial cultures was studied to maximize cellulose production, and the appropriate microbe was applied to other variables. All experiments were prepared in duplicate.

\section{Enzyme activity assay}

The enzyme was extracted by adding 5:1(w/w) distilled water to the fermented substrate. The solution was centrifuged (Dynac II centrifuge, Clay Adams range $0-4000 \mathrm{rpm}$ ) at $2500 \mathrm{rpm}$ for $15 \mathrm{~min}$ utes. The clear supernatant (crude enzyme) was subjected to measurement of cellulase activity according to modified International Union of Pure and Applied Chemistry (IUPAC) guidelines using 3,5-dinitrosalicylic acid (DNS) method.$^{25}$ Crude enzyme $(0.5 \mathrm{~mL})$ was added into $1.8 \mathrm{~mL}$ of substrate solution (1\% CM-cellulose in $1.8 \mathrm{~mL}$ of $0.05 \mathrm{M}$ phosphate citrate buffer, $\mathrm{pH} 5)$. Hydrolysis was performed by incubation at $30{ }^{\circ} \mathrm{C}$ for exactly $30 \mathrm{~min}$ utes. Glucose concentration was determined by DNS. The absorbance was measured using UV1800 spectrophotometer (Shimadzu) with the maximum wavelength $503.3 \mathrm{~nm}$. The amount of glucose released was determined by comparing it to the glucose standard curve. One IU $\mathrm{mL}^{-1}$ was defined as the amount of glucose $(\mu \mathrm{mol})$ per $\mathrm{ml}$ of enzyme solution per minute.

\section{Results and discussion}

\section{Effect of physical and biophysical pretreatments on lignin degradation}

The benefits of pretreatment for lignocellulosic biomass have been recognized for decades. ${ }^{26} \mathrm{Al}$ though the pretreatment methods to produce cellulase have been studied extensively, only a few utilize water hyacinth as a substrate. ${ }^{24,27}$ In this study, two methods of pretreatment were employed to water hyacinth. Physical pretreatment was conducted by reducing the particle size by chopping and grinding. Meanwhile, the biophysical pretreatment was the combination of physical and biological pretreatments. The reduction of particle size breaks down cellulose crystallinity and increases surface area, which may allow hydrolysis to occur more rapid$1 y .{ }^{28}$ The biophysical pretreatment was performed by exploiting white rot fungus to degrade lignin in the powdered biomass (from physical pretreatment). The biological process in biophysical pretreatment can remove lignin and hemicellulose, reduce crystallinity of cellulose, and increase porosity of the lignocellulosic materials. ${ }^{29}$ In the present study, lignin content in water hyacinth was reduced by fermentation using white rot fungus, $G$. boninense. Fig. 2 illustrates the growth of $G$. boninense as the degradation process continued up to 7 days.

Fig. 2 shows that $G$. boninense grew vigorously on the water hyacinth substrate. As $G$. boninense infected the plant, the digestion of the cell wall began. ${ }^{8,30}$ Another study revealed that the other species of Ganoderma, G. colossum, also possessed the ability to degrade lignin. ${ }^{31}$

Lignin and cellulose contents were measured and compared. Table 1 reports the effect of pretreatments on the lignin and cellulose. As illustrated in Table 1, the amount of lignin after the biophysical pretreatment relatively decreases compared to that after the physical pretreatment. It demonstrates that $G$. boninense is also capable of degrading lignin within a short time. The time it took for G. boninense to degrade lignin was 7 days. 


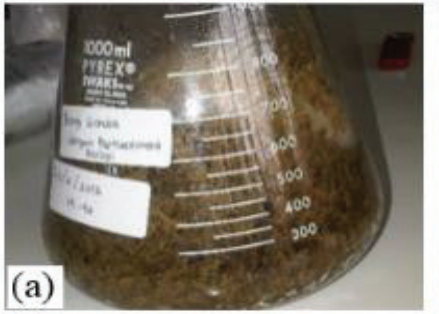

Fig. 2 - Biophysical pretreatment using G. boninense to degrade lignin in water hyacinth after (a) 2 days of incubation, (b) 7 days of incubation, and (c) washed and dried
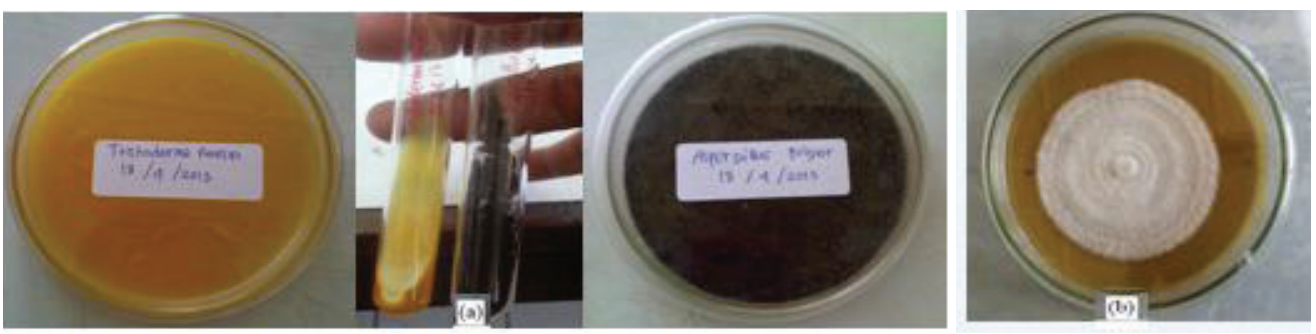

Fig. 3 - Physical appearances of fungi in PDA agar plates/slants (a) left: Trichoderma reesei; right: Aspergillus niger (b) Ganoderma boninense
Table 1 - Lignin and cellulose contents (in \% dry matter) of water hyacinth before and after pretreatments. The result was determined using Chesson method.

\begin{tabular}{lcc}
\hline Water hyacinth biomass & Lignin (\%) & Cellulose (\%) \\
\hline before pretreatment & $5.99 \pm 0.017$ & $27.78 \pm 0.012$ \\
after physical pretreatment & $4.63 \pm 0.023$ & $29.91 \pm 0.011$ \\
after biophysical pretreatment & $2.90 \pm 0.013$ & $32.20 \pm 0.021$ \\
\hline
\end{tabular}

In this study, lignin in lignocellulosic biomass is digested by the fungi's extracellular enzyme, which considerably enhances the microbes' accessibility to cellulose and potentially their cellulase production. According to other studies, ${ }^{32,33}$ the carbon source is one of the factors that influences cellulase enzyme production; the easily accessed cellulose would induce even more production. Water hyacinth is chosen as the substrate in the present study because it contains lower lignin composition compared to other lignocellulosic biomass. ${ }^{34,35}$ Since lignin binds cellulose in lignocellulosic structure, and thus inhibits cellulase production, a careful study of lignin composition is crucial. ${ }^{36}$ Nonetheless, the cellulose structure in water hyacinth requires further study because other factors beside lignin may influence cellulolytic enzyme production. ${ }^{33,37}$

\section{Effect of different fungi cultures on cellulase production}

The difference in fungi growth between Ascomycetes (A. niger and $T$. reesei) and Basidiomycetes ( $G$. boninense) could be easily observed (Fig. 3 ). The hyphae of $A$. niger and $T$. reese $i$ were spread evenly throughout the plate, while the hyphae of $G$. boninense were crowded together in one mass.

The study of microbial cellulolytic activity is essential in enzyme production. Two strains of cellulase producers, A. niger and $T$. reesei, were utilized. Both fungi cultures were fermented individually, as well as co-fermented to determine their cellulase fermenting capabilities. The results are shown in Fig. 4.

According to Fig. 4, cellulase activity is much higher when the substrate is only physically pretreated. The mono-culture fermentation of either $A$. niger or T. reesei shows higher cellulase activities than that of the mixed culture fermentation.

$A$. niger is found to be a more suitable candidate than $T$. reesei due to its production stability of cellulase, as indicated by error bars in Fig. 4. A. niger and other cellulolytic fungi have the ability to penetrate through cellulosic substrates by hyphal extensions. The rate of cellulase production is directly proportional to the growth of the fungi in the substrate.$^{38}$ Ammonium sulfate, the nitrogen source used in this study, is the most preferable nitrogen supply for Aspergillus genus. ${ }^{39,40}$ Moreover, the mixed culture fermentation process shows lower cellulolytic activity than the mono-culture fermentation. The result follows a similar trend in another study. ${ }^{37}$ They also reported that $A$. oryzae possessed higher cellulase activity than $T$. reesei. ${ }^{37}$

$A$. niger was chosen as the fermentative microbe for further experiments as it had higher and more stable cellulase activitiy, and was easier to grow in PDA slants/plates than $T$. reesei. 


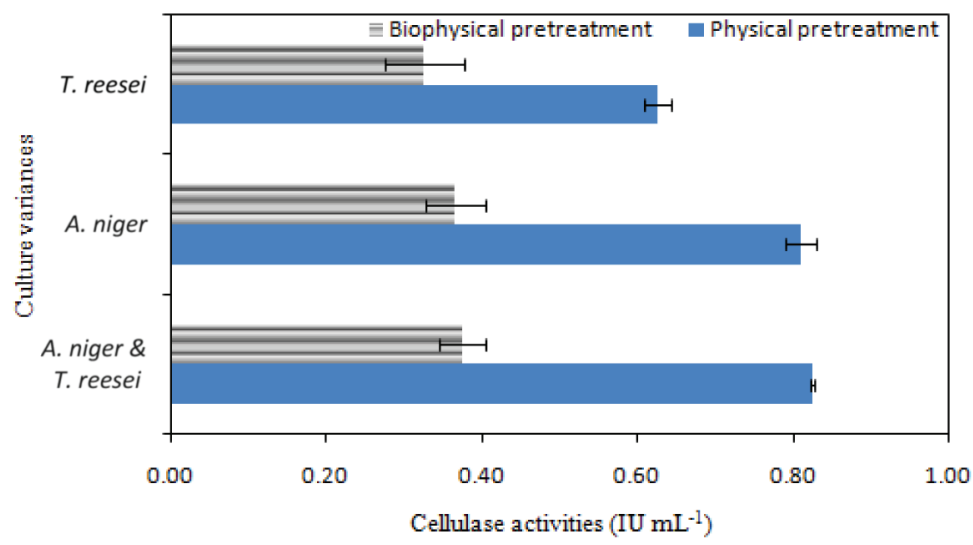

Fig. 4 -Cellulolytic activity of different fungi cultures obtained from the fermentation of pretreated water hyacinth at $30^{\circ} \mathrm{C}$ after 7 days of incubation

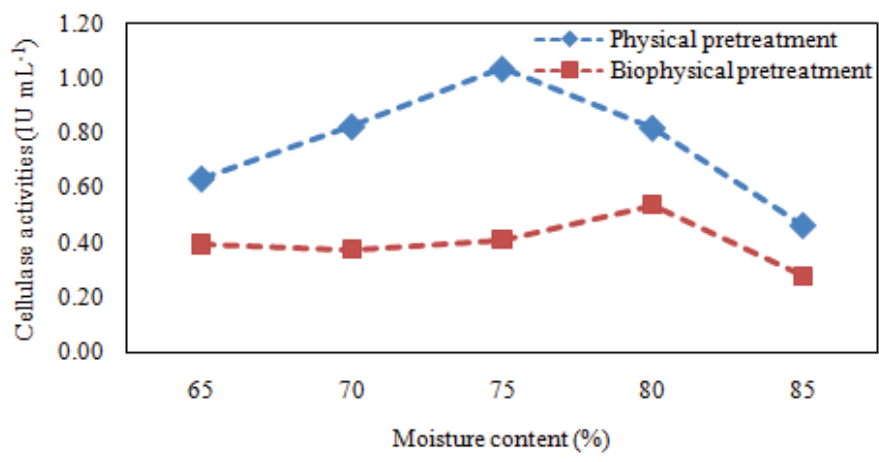

Fig. 5 - Effect of moisture content on cellulolytic activity at $30{ }^{\circ} \mathrm{C}$ after 7 days of incubation by Aspergillus niger

\section{Effect of moisture content on cellulase production}

Moisture content is an important factor for SSF since the microorganisms require a moist environment to ferment and sustain. Moisture content also has a significant effect on cellulase production. ${ }^{39,41}$ In this study, cellulase activity produced by $A$. niger was enhanced when the moisture content was higher than $70 \%$, as illustrated in Fig. 5. The optimized cellulase activities were $1.035 \mathrm{IU} \mathrm{mL}^{-1}$ and 0.535 IU mL $\mathrm{m}^{-1}$ when the moisture contents were $75 \%$ in physical pretreatment and $80 \%$ in biophysical pretreatment, respectively. Both experiments were incubated for 7 days at initial $\mathrm{pH} 5 .^{35}$ The cellulase activity of the substrate from physical pretreatment is higher than that from the biophysical counterpart.

Moisture content and temperature are two of the most important factors for incubation because they are directly related to the heat problem in fungal growth. ${ }^{42}$ They could also play a role in the oxygen level of the substrate. In this study, the optimized incubation temperature $\left(30{ }^{\circ} \mathrm{C}\right)$ according to Ilyas et al. (2011) was utilized even though the mesophilic fungi could grow well within the temperature range of $20-50{ }^{\circ} \mathrm{C} .{ }^{43}$
In addition to moisture content and temperature, $\mathrm{pH}$ can also influence the fungal growth and essentially enzyme production. The maximum cellulase production was observed in Juhasz et al. (2004) when the incubation $\mathrm{pH}$ was 5 . The similar $\mathrm{pH}$ was also utilized as the optimized $\mathrm{pH}$ in other studies. ${ }^{15,44}$ However, the result did not show significant changes when the incubation $\mathrm{pH}$ was increased. ${ }^{21}$ Thus, the optimal incubation parameters in this study were $30{ }^{\circ} \mathrm{C}$ at $\mathrm{pH} 5$.

The result from Fig. 5 indicates that cellulolytic activity, as a function of moisture content, has an optimum range between $65-80 \%(\mathrm{w} / \mathrm{w})$. The increase in cellulase activity at the specific moisture content from the experiment is relatively similar to other previous reports where lignocellulosic biomass was utilized as the carbon source, i.e wheat bran, corn bran, kinnow peel, dry orange peel, sugar cane bagasse, and soybean hulls. . $5,37,45,46$ Ilyas et al. (2011) were able to obtain $0.408 \mathrm{IU} \mathrm{mL}^{-1}$ of cellulase enzyme activity at $70 \%$ moisture content while using $V$. mungo plant as the sole carbon source. ${ }^{39}$ However, the production of cellulase is higher when the water hyacinth (E. crassipes) is employed.

The decrease in the activity after the optimal range may be related to substrate swelling, nutrient diffusion, and solubility of solid substrates. ${ }^{47}$ The excess of moisture content would lower the free air in the substrate, which would negatively affect oxygen transfer. Since oxygen is crucial to the microorganisms' growth and metabolism, the substrate should contain a suitable amount of water to maintain oxygen transfer. ${ }^{41}$

\section{Effect of incubation period on cellulase production}

The incubation period is one of the most critical aspects that affects enzyme production. At the optimized incubation period, the maximum activity was detected on the seventh day (Fig. 6). Then, the activity decreased on the eighth day and after.

The maximum enzyme activity was detected on the seventh day and began to decrease after the eighth day onward. ${ }^{44,48}$ The decrease in cellulase activity may be due to the cumulative effect of cellobiose, which is known to inhibit both endoglucanase and $\beta$-glucosidase, and deplete the nutrients. ${ }^{49-51}$

The best results of enzyme production in this study occurred in the physical pretreatment substrate. Although the lignin content after the biophysical pretreatment had reduced, it did not indicate an increment in enzyme production as evident 


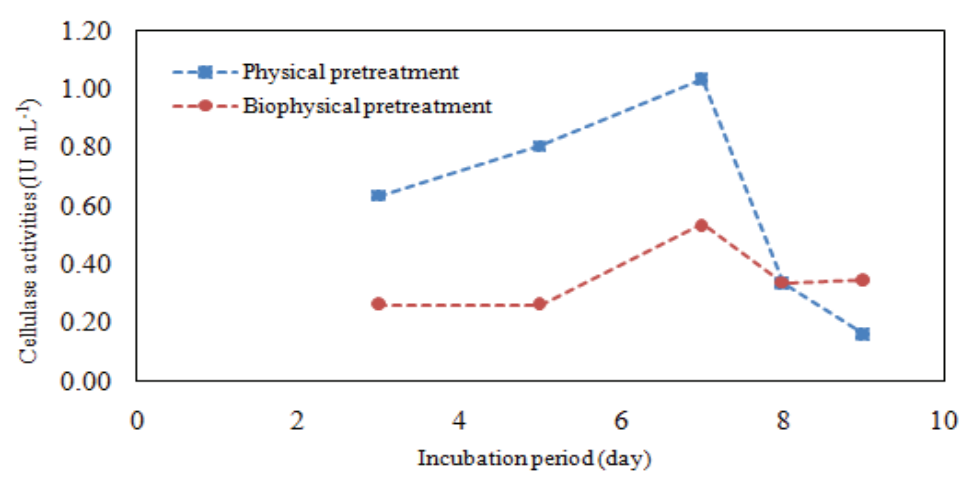

Fig. 6 - Effect of incubation period on cellulolytic activity by Aspergillus niger. The moisture contents for the physical and combined pretreatments were adjusted to $75 \%$ and $80 \%$, respectively. The incubation temperature was $30^{\circ} \mathrm{C}$

in Fig. 3 to Fig. 6. The crystalline structure of cellulose may positively influence the production of cellulase.

The maximum cellulase production from this study was $1.035 \mathrm{IU} \mathrm{mL}^{-1}$ when the physically pretreated water hyacinth was incubated with $A$. niger. This result was proportionally similar to other cellulase production studies from other carbon source, i.e. ground nut shell. The higher cellulose composition $(65.7 \%)$ of ground nut shell caused the cellulase to be produced at $1.539 \mathrm{IU} \mathrm{mL}^{-1}$ using A. terreus. ${ }^{40}$ Jabasingh et al. (2014) used coir pith as carbon source, which contains similar cellulose composition to that of water hyacinth. The obtained cellulase enzymes production was $60.532 \mathrm{U} \mathrm{mL}^{-1}$ using $A$. nidulans ${ }^{35}$ Although, several other conditions should be further investigated in cellulase production studies, water hyacinth remains the potential candidate for the carbon source in future research.

\section{Crystallinity measurement of the biomass related to cellulase production}

The results demonstrated that lower lignin content does not positively contribute to higher cellu-

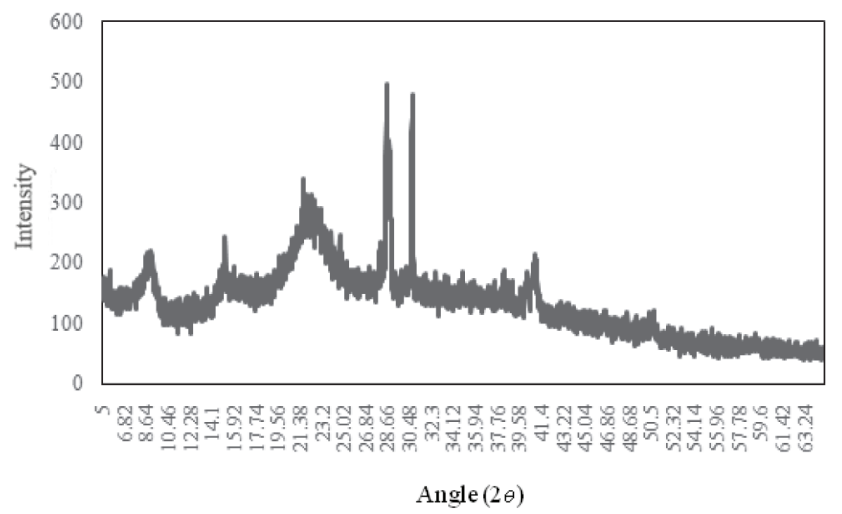

lase production. One study suggests that cellulose crystallinity may significantly affect the production of cellulolytic enzyme. ${ }^{37}$ Exposure of crystallinity would stimulate the production of cellulase from Trichoderma reesei and Aspergillus oryzae. This means that larger apparent crystallinity of cellulose would induce a higher production rate of exo- and endoglucanase from the microorganisms. In addition, the crystalline structure of the carbon source may also result in an increment of cellulolytic expression in many fungi. ${ }^{52}$

The crystallinity of biomass can be determined using X-Ray Diffractometers (XRD). The XRD diffractograms in Fig. 7a and $b$ measured the crystallinity of water hyacinth substrate after the physical and biophysical pretreatments.

The percentage of apparent crystallinity was calculated by comparing the intensity of the crystalline peak to the total intensity. The apparent crystallinity of water hyacinth after the physical and biophysical pretreatments was $56.9 \%$, and $53.6 \%$, respectively. The crystalline measurements demonstrated the organisms' abilities to break down crystalline content in water hyacinth and produce cellulase.

\section{Conclusions}

Water hyacinth could be utilized as the substrate for cellulase production. The best microbe to produce cellulase in this study was Aspergillus niger for both physical and biophysical pretreatments. Physical pretreatment gave higher cellulase production than biophysical pretreatment. The maximum cellulase activities after 7 days of incubation were $1.035 \mathrm{IU} \mathrm{mL}^{-1}$ and $0.535 \mathrm{IU} \mathrm{mL}^{-1}$ when the moisture contents were $75 \%$ and $80 \%$, respectively, at $30{ }^{\circ} \mathrm{C}$ with initial pH 5 .

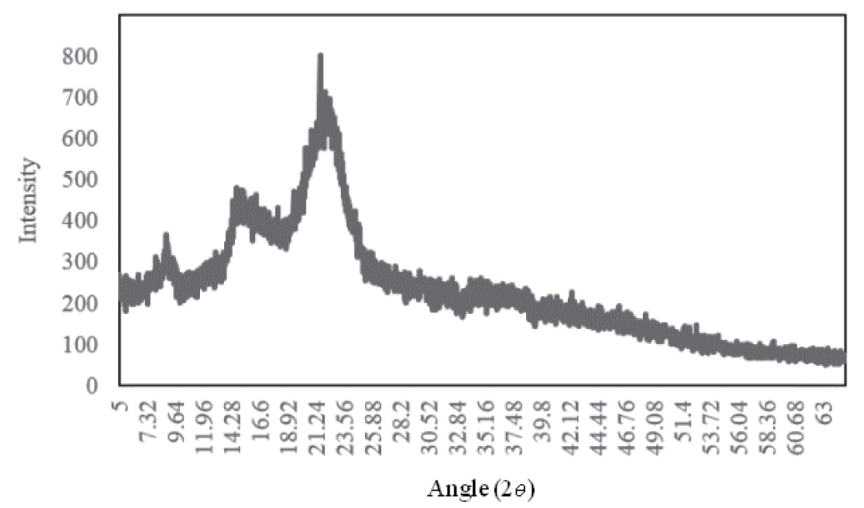

Fig. 7 - Diffractograms of water hyacinth after a) physical, and b) biophysical pretreatment 


\section{ACKNOWLEDGEMENT}

The authors would like to acknowledge Bandung Institute of Technology, Indonesia Endowment Fund for Education, Jakarta, Indonesia, and Hungarian Scientific Research Fund (OTKA/NKFIH $P D$-108389) for financial support.

\section{References}

1. Jafari, N. J., Ecological and socio-economic utilization of water hyacinth (E. crassipes mart solms), Appl. Sci. Enviromental Manag. 14 (2010) 43. doi: http://dx.doi.org/10.1371/journal.pone.0013200

2. Shanab, S. M. M., Shalaby, E. A., Lightfoot, D. A., El-She$m y, H$. A., Allelopathic effects of water hyacinth $(E$. crassipes), PLoS One 5 (2010) 1. doi: http://dx.doi.org/10.3391/ai.2008.3.1.8

3. Téllez, T. R., López, E., Granado, G., Pérez, E., López, R., Guzmán, J., The water hyacinth, Eichhornia crassipes: an invasive plant in the Guadiana River Basin (Spain), Aquat. Invasions 3 (2008) 42.

4. Ando, S., Arai, I., Kiyoto, K., Hanai, S. J., Identification of aromatic monomers in steam-exploded poplar and their influences on ethanol fermentation by Saccharomyces cerevisiae, Ferment. Technol. 64 (1986) 567.

doi: http://dx.doi.org/10.1016/0385-6380(86)90084-1

5. Phitsuwan, P., Laohakunjit, N., Kerdchoechuen, O., Kyu, K. L., Ratanakhanokchai, K., Present and potential applications of cellulases in agriculture, biotechnology, and bioenergy, Folia Microbiol. 58 (2013) 163.

doi: http://dx.doi.org/10.1007/s12223-012-0184-8

6. Herculano, P. N. Porto, T. S., Moreira, K. A., Pinto, G. A. S., Souza-Motta, C. M., Porto, A. L. F., Cellulase production by Aspergillus japonicus URM5620 using waste from castor bean (Ricinus communis L.) under solid state fermentation, Appl. Biochem. Biotechnol. 165 (2011) 1057. doi: http://dx.doi.org/10.1007/s12010-011-9321-0

7. Mosier, N. Wyman, C., Dale, B., Elander, R., Lee, Y. Y., Holtzapple, M., Ladisch, M., Features of promising technologies for pretreatment of lignocellulosic biomass, Bioresour. Technol. 96 (2005) 673. doi: http://dx.doi.org/10.1016/j.biortech.2004.06.025

8. Hushiarian, R., Yusof, N. A., Dutse, S. W., Detection and control of Ganoderma boninense: strategies and perspectives, Springer Plus 2 (2013) 555.

doi: http://dx.doi.org/10.1186/2193-1801-2-555

9. Blanchette, R. A., Screening wood decayed by white rot fungi for preferential lignin degradation, Appl. Environ. Microbiol. 48 (1984) 647.

10. Reith, J. H., Uil, H. D., Veen, H. V., Niessen, J. J., Jong, E. D., Elbersen, H. W., Dijken, J. P. V., Raamsdonk, L., 12th european conference and technology exhibition on biomass for energy, (2002) 3.

11. Singhania, R. R., Sukumaran, R. K., Patel, A. K., Larroche, $C$., Pandey, A., Advancement and comparative profiles in the production technologies using solid-state and submerged fermentation for microbial cellulases, Enzyme Microb. Technol. 46 (2010) 541. doi: http://dx.doi.org/10.1016/j.enzmictec.2010.03.010

12. Bhat, M. K., Cellulases and related enzymes in biotechnology, Biotechnol. Adv. 18 (2000) 355. doi: http://dx.doi.org/10.1016/S0734-9750(00)00041-0

13. Olsson, L., Christensen, T. M. I. E., Hansen, K. P., Palmqvist, E. A., Influence of the carbon source on production of cellulases, hemicellulases, and pectinases by Trichoderma reesei Rut C-30, Enzyme Microb. Technol. 33 (2003) 612. doi: http://dx.doi.org/10.1016/S0141-0229(03)00181-9

14. Sukumaran, R. K., Singhania, R. R., Mathew, G. M., Pand$e y, A$., Cellulase production using biomass feed stock and its application in lignocellulose saccharification for bio-ethanol production, Renew. Energy 34 (2009) 421. doi: http://dx.doi.org/10.1016/j.renene.2008.05.008

15. Kumar, S., Sharma, H. K., Sarkar, B. C., Effect of substrate and fermentation conditions on pectinase and cellulase production by Aspergillus niger NCIM 548 in submerged $(\mathrm{SmF})$ and solid state fermentation (SSF), Food Sci. Biotechnol. 20 (2011) 1289. doi: http://dx.doi.org/10.1007/s10068-011-0178-3

16. Miranda Junior, M., Batistote, M., Cilli, E. M., Ernandes, J. $R$., Sucrose fermentation by Brazilian ethanol production yeasts in media containing structurally complex nitrogen sources, J. Inst. Brew. 115 (2009) 191. doi: http://dx.doi.org/10.1002/j.2050-0416.2009.tb00368.x

17. Rashid, S. S., Alam, M. Z., Karim, M. I. A., Salleh, M. H., Management of palm oil mill effluent through production of cellulases by filamentous fungi, World J. Microbiol. Biotechnol. 25 (2009) 2219. doi: http://dx.doi.org/10.1007/s11274-009-0129-9

18. Datta, R., Acidogenic fermentation of lignocellulose-acid yield and conversion of components, Biotechnol. Bioeng. 23 (1981) 2167. doi: http://dx.doi.org/10.1002/bit.260230921

19. Terinte, N., Ibbett, R., Schuster, K. C., Overview on native cellulose and microcrystalline cellulose I structure studied by x-ray diffraction (WAXD): comparison between measurement techniques, Lenzinger Berichte. 89 (2011) 118.

20. Segal, L., Creely, J. J., Martin, A. E., Conrad, C. M., An empirical method for estimating the degree of crystallinity of native cellulose using the x-ray diffractometer, Text. Res. J. (1959) 786. doi: http://dx.doi.org/10.1177/004051755902901003

21. Juhasz, T., Szengyel, Z., Szijarto, N., Reczey, K., Effect of $\mathrm{pH}$ on cellulase production of Trichoderma reesei RUT C30, Appl. Biochem. Biotechnol. 113 (2004) 201. doi: http://dx.doi.org/10.1385/ABAB:113:1-3:201

22. Oberoi, H. S., Chavan, Y., Bansal, S., Dhillon, G. S., Production of cellulases through solid state fermentation using kinnow pulp as a major substrate, Food Bioprocess Technol. 3 (2010) 528. doi: http://dx.doi.org/10.1007/s11947-008-0092-8

23. Mrudula, S., Murugammal, R., Production of cellulase by Aspergillus niger under submerged and solid state fermentation using coir waste as a substrate, Brazilian J. Microbiol. 42 (2011) 1119. doi: http://dx.doi.org/10.1590/S1517-83822011000300033

24. Deshpande, P., Nair, S., Khedkar, S., Water hyacinth as carbon source for the production of cellulase by Trichoderma reesei, Appl. Biochem. Biotechnol. 158 (2009) 552. doi: http://dx.doi.org/10.1007/s12010-008-8476-9

25. Ghose, T. K., Measurement of cellulase activities, Int. Union Pure Appl. Chem. 59 (1987) 257.

26. McMillan, J. D., Bioethanol production: status and prospects, Renew. Energy. 10 (1997) 295. doi: http://dx.doi.org/10.1016/0960-1481(96)00081-X

27. Abo-Elmagd, H. I., Housseiny, M. M., Purification and characterization of carboxymethyl cellulase and protease by Ulocladium botrytis preuss ATCC 18042 using water hyacinth as a substrate under solid state fermentation, Ann. Microbiol. 62 (2012) 1547. doi: http://dx.doi.org/10.1007/s13213-011-0409-0 
28. Lee, J., Parameswaran, B., Lee, J., Park, S. C., Recent developments of key technologies on cellulosic ethanol production, Sci. Ind. Res. 67 (2008) 865

29. Kumar, P., Barrett, D. M., Delwiche, M. J., Stroeve, P., Methods for pretreatment of lignocellulosic biomass for efficient hydrolysis and biofuel production, Ind. Eng. Chem. Res. 48 (2009) 3713 doi: http://dx.doi.org/10.1021/ie801542g

30. Pilotti, C. A., Sanderson, F. R., Aitken, E. A. B., Genetic structure of a population of Ganoderma boninense on oil palm, Plant Pathol. 52 (2003) 455. doi: http://dx.doi.org/10.1046/j.1365-3059.2003.00870.x

31. Adaskaveg, J. E., Gilbertson, R. L., Dunlap, M. R., Effects of incubation time and temperature on in vitro selective delignification of silver leaf oak by Ganoderma colossum, Appl. Environ. Microbiol. 61 (1995) 138.

32. Biswas, R., Production of cellulolytic enzymes, Bioprocessing of renewable resources to commodity bioproducts, First ed, John Wiley \& Sons, Inc., New York, 2014, pp105-132.

33. Yang, B., Dai, Z., Ding, S., Wyman, C. E., Enzymatic hydrolysis of cellulosic biomass, Biofuels 2 (2011) 421. doi: http://dx.doi.org/10.4155/bfs.11.116

34. Jabasingh, S. A., Response surface methodology for the evaluation and comparison of cellulase production by $A s$ pergillus nidulans SU04 and Aspergillus nidulans MTCC344 cultivated on pretreated sugarcane bagasse, Chem. Biochem. Eng. Q. 25 (2011) 501.

35. Jabasingh, S. A., Varma, S., Garre, P., Production and purification of cellulase from Aspergillus nidulans AJSU04 under solid-state fermentation using coir pith, Chem. Biochem. Eng. Q. 28 (2014) 143.

36. Wyman, C. E., Dale, B. E., Elander, R. T., Holtzapple, M., Ladisch, M. R., Lee, $Y Y$., Coordinated development of leading biomass pretreatment technologies, Bioresour. Technol. 96 (2005) 1959. doi: http://dx.doi.org/10.1016/j.biortech.2005.01.010

37. Brijwani, K., Vadlani, P. V., Cellulolytic enzymes production via solid-state fermentation: effect of pretreatment methods on physicochemical characteristics of substrate, Enzyme Res. (2011).

38. Eriksson, K.-E., L., Blanchette, R. A., Ander, P., Microbial and enzymatic degradation of wood and wood components. Springer Verlag New York Inc., Secaucus New Jersey USA Berlin Germany, 1990.

39. Ilyas, U., Majeed, A., Hussain, K., Nawaz, K., Ahmed, S., Nadeem, M., Solid state fermentation of Vigna mungo for cellulase production by Aspergillus niger, World Appl. Sci. J. 12 (2011) 1172.

40. Vyas, A., Vyas, D., Vyas, K. M., Production and optimization of cellulases on pretreated groundnut shell by Aspergillus terreus AV49, J. Sci. Ind. Res. 64 (2005) 281.
41. Liu, J., Yang, J., Cellulase production by Trichoderma koningii AS3.4262 in solid-state fermentation using lignocellulosic waste from the vinegar industry, Food Technol. Biotechnol. 45 (2007) 420-425.

42. Bhargav, S., Panda, B. P., Ali, M., Javed, S., Solid-state fermentation: an overview Chem. Biochem. Eng. Q. 22 (2008) 49.

43. Tuomela, M., Vikman, M., Hatakka, A., Itavaara, M., Biodegradation of lignin in a compost environment: a review, Bioresour. Technol. 72 (2000) 169. doi: http://dx.doi.org/10.1016/S0960-8524(99)00104-2

44. Devi, M., Kumar, M., Production, optimization and partial purification of cellulase by Aspergillus niger fermented with paper and timber sawmill industrial wastes, J. Microbiol. Biotechnol. Res. 2 (2012) 120.

45. Delabona, P. D. S., Pirota, R. D. P. B., Codima, C. A., Tremacoldi, C. R., Rodrigues, A., Farinas, C. S., Effect of initial moisture content on two amazon rainforest Aspergillus strains cultivated on agro-industrial residues: biomass-degrading enzymes production and characterization, Ind. Crops Prod. 42 (2013) 236. doi: http://dx.doi.org/10.1016/j.indcrop.2012.05.035

46. Mamma, D., Kourtoglou, E., Christakopoulos, P., Fungal multienzyme production on industrial by-products of the citrus-processing industry, Bioresour. Technol. 99 (2008) 2373. doi: http://dx.doi.org/10.1016/j.biortech.2007.05.018

47. Saliman, H. M., Sherief, A. D. A., El-Tanash, A. B., Production of xylanase by Aspergillus niger and Trichoderma viride using some agriculture residues, Int. J. Agric. Res. 7 (2012) 46 . doi: http://dx.doi.org/10.1016/j.biortech.2007.05.018

48. Jahangeer, S., Khan, N., Jahangeer, S., Sohail, M., Shahzad, S., Ahmad, A., Khan, S. A., Screening and characterization of fungal cellulases isolated from the native environmental source, Pakistan J. Bot. 37 (2005) 739.

49. Howell, J. A., Mangat, M., Enzyme deactivation during cellulose hydrolysis, Biotechnol. Bioeng. 20 (1978) 847. doi: http://dx.doi.org/10.1002/bit.260200607

50. Hsieh, H. J., Liu, P. C., Liao, W. J., Immobilization of invertase via carbohydrate moiety on chitosan to enhance its thermal stability, Biotechnol. Lett. 22 (2000) 1459. doi: http://dx.doi.org/10.1023/A:1005602812037

51. Singh, A., Singh, N., Bishnoi, N. R., Production of cellulases by Aspergillus heteromorphus from wheat straw under submerged fermentation, Int. J. Civ. Environ. Eng. 1 (2009) 23.

52. Meshartree, M., Hogan, C. M., Saddler, J., Influence of growth substrate on production of cellulase enzymes by Trichoderma harzianum E58, Biotechnol. Bioeng. 31 (1988) 725 . 